\title{
Phylogeny and Taxonomy of Mesophilic Methanococcus spp. and Comparison of rRNA, DNA Hybridization, and Phenotypic Methods
}

\author{
J. KESWANI, ${ }^{1}$ S. ORKAND, ${ }^{1}$ U. PREMACHANDRAN,${ }^{1}$ L. MANDELCO, ${ }^{2}$ M. J. FRANKLIN, ${ }^{1}$ \\ AND W. B. WHITMAN ${ }^{1 *}$ \\ Department of Microbiology, University of Georgia, Athens, Georgia 30602-2605, ${ }^{1}$ and Department of \\ Microbiology, University of Illinois, Urbana, Illinois $61801^{2}$
}

\begin{abstract}
The phylogeny and taxonomy of the mesophilic methane-producing archaea of the order Methanococcales were examined by DNA relatedness, 16S rRNA sequence analysis, cellular protein pattern, and phenotypic methods. The mesophilic species Methanococcus maripaludis, Methanococcus vannielii, Methanococcus voltaei, and "Methanococcus aeolicus" formed a deep group with 5 to 30\% DNA relatedness and 92 to 96\% 16S rRNA sequence similarity. Twenty-two additional isolates and Methanococcus deltae were similar to the type strain of either $M$. voltaei or $M$. maripaludis. Two isolates, strains A2 and A3, exhibited 37\% DNA relatedness and $99.2 \%$ 16S rRNA sequence similarity to $M$. voltaei $\operatorname{PS}^{\mathrm{T}}(\mathrm{T}=$ type strain). In the absence of phenotypic differences, these organisms were assigned to $M$. voltaei. Similarly, four autotrophic isolates, strains $\mathrm{C5}, \mathrm{C6}, \mathrm{C} 7$, and $\mathrm{C8}$, exhibited 54 to $69 \%$ DNA relatedness and $99.2 \% 16 \mathrm{~S}$ rRNA sequence similarity to $M$. maripaludis $\mathrm{JJ}^{\mathrm{T}}$ and were assigned to $M$. maripaludis. While these isolates were sufficiently genetically diverse to justify classification in novel species, few differences were apparent in the phenotypic properties available for measurement. Thus, the phenotypic properties of these lithotrophic archaea were highly conserved and poor indicators of genetic diversity. Partial sequencing of about 200 bases of both the $16 \mathrm{~S}$ and $23 \mathrm{~S}$ rRNAs of the isolates demonstrated allelic diversity within methanococcal species. This allelic diversity did not correlate with diversity measured by DNA relatedness, cellular protein pattern, and other methods. Similarly, antisera to whole cells of the type strains did not cross-react strongly to whole cells of strains that were genetically similar, and serological cross-reactivity was not a useful taxonomic method for methanococci. Lastly, on the basis of the results of $16 \mathrm{~S}$ rRNA sequence analyses and biochemical data, the ancestor of the mesophilic methanococci may have been an autotrophic thermophile.
\end{abstract}

The genus Methanococcus belongs to the family Methanococcaceae and the order Methanococcales, which is one of five orders within the Archaea that include methanogenic bacteria (3). The order Methanococcales is composed of coccoid methane-producing bacteria of marine origin. Distinctive features of this group include rapid growth at either mesophilic or thermophilic temperatures, cell envelopes composed of protein S-layers, and a nutritional requirement for selenium $(6,18$, 23, 44, 45). To date, eight Methanococcales species belonging to two families and four genera have been described. Five species, Methanococcus vannielii, Methanococcus voltaei, Methanococcus maripaludis, Methanococcus deltae, and "Methanococcus aeolicus," are mesophilic, and three species, Methanococcus ("Methanothermococcus") thermolithotrophicus, Methanococcus ("Methanoignis") igneus, and Methanococcus ("Methanocaldococcus") jannaschii (4) (proposed genus names in parentheses), are thermophilic. The relationships of all of the mesophilic species except " $M$. aeolicus" have been determined by $16 \mathrm{~S}$ rRNA cataloging studies (24). Therefore, to establish the phylogenetic relationships of the mesophilic species in accordance with the recommendations of the International Committee on Systematic Bacteriology Subcommittee for Taxonomy of Methanogenic Bacteria (3), the levels of sequence similarity of nearly complete $16 \mathrm{~S}$ rRNA sequences and DNA-DNA hybridization values were determined.

Historically, the systematics of methanococci has been hindered by the absence of information on the reliability of phe-

* Corresponding author. Phone: (706) 542-4219. Fax: (706) 5422674. Electronic mail address: whitman@uga.cc.uga.edu. notypic characters and other taxonomic tests for distinguishing species. In part, this situation resulted from the laborious culture techniques required for these hydrogenotrophic methanogens, the absence of multiple isolates of the same species, and the difficulty of performing simple growth experiments. Thus, a major goal of the studies reported here was to evaluate the various taxonomic methods for classification of the methanococci. In addition, modern bacterial systematics has sought to define species of similar genetic and phenotypic diversity across many taxa (43). However, many of the classical methods applied to other bacterial groups have not been used for the methanococci and many other archaea. Instead, methanococcal systematics has relied heavily on 16S rRNA sequencing and cataloging. Thus, it has not been possible to make direct comparisons between different methods of measuring diversity within the methanococci and other archaea. To this end, the diversity of the methanococci was examined by classical methods, including DNA hybridization and cellular protein analysis methods, for comparison with rRNA sequence data.

In addition, 22 mesophilic methanococci which previously had been isolated from anaerobic sediments from Georgia and Florida (45) were studied. These isolates shared a set of phenotypic characteristics that included utilization of $\mathrm{H}_{2}$ plus $\mathrm{CO}_{2}$ or formate as an energy source, susceptibility to detergents, and susceptibility to low-ionic-strength buffers. They clustered into two groups on the basis of their DNA base compositions and nutritional requirements. In this paper, we describe additional phenotypic and genetic approaches that were used to further differentiate the isolates and determine their relatedness. 


\section{MATERIALS AND METHODS}

Sources and growth of bacteria. $M$. vannielii $\mathrm{SB}^{\mathrm{T}}$ (= DSM $1224^{\mathrm{T}}$ [Deutsche Sammlung von Mikroorganismen, Braunschweig, Germany] $=\mathrm{OCM} 148^{\mathrm{T}}$ [Oregon Collection of Methanogens, Beaverton] $)(T=$ type strain) was obtained from W. E. Balch. M. maripaludis $\mathrm{JJ}^{\mathrm{T}}\left(=\mathrm{DSM} 2067^{\mathrm{T}}=\mathrm{OCM} 175^{\mathrm{T}}\right)$ was obtained from W. J. Jones. M. voltaei PS $\left(=\right.$ DSM $1537^{\mathrm{T}}=$ OCM $\left.70^{\mathrm{T}}\right)$ was obtained from P. H. Smith. "M. aeolicus" was obtained from K. O. Stetter. M. deltae $\Delta \mathrm{RC}^{\mathrm{T}}\left(=\mathrm{DSM} 2771^{\mathrm{T}}=\right.$ OCM $\left.151^{\mathrm{T}}\right)$ was obtained from L. A. Hook. The sources of other mesophilic Methanococcus strains have been described previously (45). Except for "M. aeolicus," which is available from K. O. Stetter, these strains are available from us. The following strains are also available from the Oregon Collection of Methanogens: strains A3 (= OCM 197), C2 (= OCM 233), C4 (= OCM 232), C5 (= OCM 209), C6 (= OCM 363), and C7 (= OCM 364). Complex medium $\mathrm{McC}$ was used for the growth of various methanococci as described previously (45).

Indirect immunofluorescence. Antisera to whole cells of $M$. voltaei $\mathrm{PS}^{\mathrm{T}}, M$. maripaludis $\mathrm{JJ}^{\mathrm{T}}$, and $M$. vannielii $\mathrm{SB}^{\mathrm{T}}$ were prepared in goats as described previously (36), except that the immunization dose was increased 10 -fold. The indirect immunofluorescence test was performed by the method of Conway de Macario et al. (8), as modified by Franklin et al. (17).

Cell size. A small portion $(10 \mu \mathrm{l})$ of an early-stationary-phase culture was placed on an agar-coated slide and photographed by phase-contrast microscopy. Photographic negatives were projected in a photoenlarger, and the diameters of 50 cells were measured. Controls indicated that the cell diameter measured by this method was reproducible in replicate cultures and at different stages of growth if care was taken to prevent drying of the sample (44).

Electrophoretic analysis of whole-cell proteins. Cell pellets from $5.0-\mathrm{ml}$ cultures grown to an $A_{660}$ of $1.0 \mathrm{~cm}^{-1}$ were harvested anaerobically in the culture tubes by centrifugation with an IEC model CRU-5000 centrifuge at $2,000 \times g$ for $20 \mathrm{~min}$ at room temperature. The cell pellets were resuspended in $0.1 \mathrm{ml}$ of $\mathrm{Mc}$ buffer, which contained $50 \mathrm{ml}$ of glass-distilled water, $50 \mathrm{ml}$ of a general salts solution (4.5 mM KCl, $13.5 \mathrm{mM} \mathrm{MgCl}_{2}, 14.0 \mathrm{mM} \mathrm{MgSO}_{4}, 9.0 \mathrm{mM} \mathrm{NH}_{4} \mathrm{Cl}, 0.95$ $\mathrm{mM} \mathrm{CaCl}{ }_{2}, 0.8 \mathrm{mM} \mathrm{K} \mathrm{HPO}_{4}$ ), and $7.5 \mathrm{ml}$ of $5 \mathrm{M} \mathrm{NaCl}$. The suspensions were stored in $15-\mu \mathrm{l}$ portions at $-20^{\circ} \mathrm{C}$. For extraction of proteins, a portion of a suspension was allowed to thaw on ice, immediately mixed with $60 \mu \mathrm{l}$ of sample buffer containing sodium dodecyl sulfate (SDS) and 2-mercaptoethanol, and heated in a boiling water bath for $5 \mathrm{~min}(27)$. Portions $(35 \mu \mathrm{l})$ were subjected to electrophoresis in $12 \%$ polyacrylamide gels containing SDS as described previously (27). The molecular weight standards used were obtained from Sigma Chemical $\mathrm{Co}$. and included (molecular weight in parentheses): $\alpha$-lactalbumin $(14,200)$, trypsin inhibitor $(20,100)$, trypsinogen $(24,000)$, carbonic anhydrase $(29,000)$, glyceraldehyde-3-phosphate dehydrogenase $(36,000)$, egg albumin $(45,000)$, and bovine albumin $(66,000)$. Each gel was stained with Coomassie bluc.

To determine relatedness from whole-cell protein patterns, the stained gels were photographed. Each lane in the photographs was then cut out so that pairwise comparisons could be made visually by placing lanes representing pairs of strains next to each other. Levels of similarity were calculated by dividing the number of bands that had identical mobilities and intensities in both lanes by the average number of total bands in each lane. In general, the 30 to 32 darkes bands were compared. The similarity values were analyzed by cluster analysis, using the unweighted pair group method with averages (UPGMA) contained in the PHYLIP version 3.5 package. The cophenetic correlation coefficient for this analysis was $0.807(39)$. The results obtained with controls indicated that the protein patterns for cultures at different stages of the growth cycle and in complex and defined media were indistinguishable by this technique.

Preparation of DNA. All strains were grown anaerobically to the late exponential growth phase. Cell pellets from 200 -ml portions of cultures were collected aerobically by centrifugation at $10,000 \mathrm{rpm}$ for $15 \mathrm{~min}$ with a Beckman centrifuge by using a type JA-14 rotor at $15^{\circ} \mathrm{C}$. For DNA extraction, the general procedure of Meakin et al. (31) was used with the following modifications: the procedure was scaled up from 10- to $200-\mathrm{ml}$ cultures; cells were resuspended in $10 \mathrm{ml}$ of sterile Mc buffer; proteinase K, dithiothreitol, and SDS were added; and the suspensions were incubated for $1 \mathrm{~h}$ at $37^{\circ} \mathrm{C}$. The total nucleic acids were recovered after precipitation of the cell debris as described previously (31). To remove RNA, $10 \mu$ l of RNase A and $15 \mu$ l of RNase $T_{1}\left(3 \mathrm{mg} \mathrm{ml}^{-1} ; 5\right.$ Prime - 3 Prime, Inc., Boulder, Colo.) were added, and the extract was incubated at $37^{\circ} \mathrm{C}$ for $1 \mathrm{~h}$ The sample was then extracted twice with an equal volume of phenol-chloroform-isoamyl alcohol $(25: 24: 1, \mathrm{vol} / \mathrm{vol} / \mathrm{vol})$ and twice with chloroform. After ammonium acetate had been added to a final concentration of $0.5 \mathrm{M}$, the DNA was precipitated by adding 2.5 volumes of cold ethanol. The pellet was dried under a vacuum for $5 \mathrm{~min}$ and resuspended in $1.0 \mathrm{ml}$ of $0.02 \mathrm{M} \mathrm{NaCl}$ in $1 \mathrm{mM}$ HEPES ( $N$-2-hydroxyethyl-1-piperazine- $N^{\prime}$-2-ethanesulfonic acid) buffer ( $\mathrm{pH}$ $7.0)$.

The DNA concentration was calculated from the $A_{260}$ by assuming that a DNA solution with a concentration of $50 \mu \mathrm{g} / \mathrm{ml}$ gives an $A_{260}$ value of 1.0 . The purity of the DNA was determined by UV spectral analysis. This method yielded DNA with an $A_{260} / A_{280}$ ratio of 1.9 , which indicated that it was very pure. The degree of nicking of the DNA was determined by agarose gel electrophoresis of both native and denatured DNAs (34). In the native form, the DNA had a low electrophoretic mobility and formed a narrow band $\left(M_{\mathrm{r}},>23,000 \mathrm{bp}\right)$. The denatured DNA always had a broad electrophoretic mobility $\left(M_{\mathrm{r}}, 800\right.$ to 23,000 $\mathrm{bp}$ ), indicating that nicks were present.

For unlabeled DNA, the nicks in the duplex DNA were partially repaired by treating the preparation with T4 DNA ligase for at least $12 \mathrm{~h}$ at $4^{\circ} \mathrm{C}(29)$. This step was necessary to prevent formation of DNA fragments less than 800 bases long during shearing and denaturation. After denaturation, the $M_{\mathrm{r}}$ was 20,000 to $23,000 \mathrm{bp}$, indicating that partial repair had occurred. The enzyme was then denatured by heating the preparation at $70^{\circ} \mathrm{C}$ for $10 \mathrm{~min}$, and the DNA was precipitated with ethanol. The resulting pellet was dried and resuspended in 1.0 $\mathrm{ml}$ of buffer as described above. The DNA concentration was adjusted to $0.4 \mu \mathrm{g}$ $\mu \mathrm{l}^{-1}$, and $2.0 \mathrm{ml}$ of the solution was passed through a miniature French pressure cell at a pressure of $5.5 \mathrm{mPa}$. As determined by agarose gel electrophoresis, the $M_{\mathrm{r}}$ of the DNA was 800 to $1,500 \mathrm{bp}$.

For radiolabeled DNA, the DNA was not repaired, but it was nick translated by using $\alpha-{ }^{35}$-labeled dATP and a nick translation kit (BRL, Life Technologies, Inc., Gaithersburg, Md.), except that the enzyme mixture containing DNase I and DNA polymerase I was replaced by DNA polymerase I alone (Promega Corp.). The unincorporated nucleotides were removed with NucTrap push columns (Stratagene). In some preparations, the sizes of the radiolabeled fragments were determined after electrophoresis on native agarose gels. The gels were dried on Whatman 3MM filter paper by using a gel dryer and exposed to film at room temperature for 2 to 4 days. The radiolabeled DNA generally had a broad $M_{r}$ (600 to $1,000 \mathrm{bp})$.

DNA-DNA hybridization. Solution hybridization was performed in two steps by using the general S1 nuclease procedure of Johnson (22). The first step involved reassociation of DNA with the following modifications. The reassociation mixture was reduced to a total volume of $55 \mu l$ and contained $5 \mu \mathrm{l}(15,000$ cpm; $0.015 \mu \mathrm{g}$ or less) of radiolabeled DNA, $25 \mu \mathrm{l}\left(0.4 \mu \mathrm{g} \mu \mathrm{l}^{-1} ; 10 \mu \mathrm{g}\right)$ of unlabeled and fragmented DNA, $12.5 \mu \mathrm{l}$ of a buffer that contained $1.1 \mathrm{M} \mathrm{NaCl}$ and $1 \mathrm{mM}$ HEPES ( $\mathrm{pH} 7.0$ ), and $12.5 \mu \mathrm{l}$ of deionized formamide prepared as described previously (29). The reaction mixtures were incubated completely submerged in a water bath at $25^{\circ} \mathrm{C}$ below the denaturation temperature $\left(T_{m}\right)$ of the radiolabeled DNA. The $T_{m}$ was calculated from the $\mathrm{G}+\mathrm{C}$ content $(45)$ by using the equation $T_{m}=64.9^{\circ} \mathrm{C}+0.5025(\mathrm{G}+\mathrm{C}$ content $)$ and was further reduced by $0.62^{\circ} \mathrm{C}$ for each $1 \%$ formamide in the solution. The second step involved treating the reassociated DNA with S1 nuclease (Promega Corp.). The modifications of the S1 nuclease procedure used included reduction of the volume of the assay mixture to $655 \mu \mathrm{l}$ and incubation of the reaction mixtures at

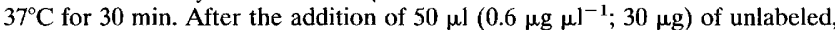
native, sheared salmon sperm DNA as a carrier, $\mathrm{S} 1$ nuclease-resistant fragments were precipitated with an equal volume of $10 \%$ trichloroacetic acid containing $1 \%$ sodium pyrophosphate. The precipitates were collected on $0.22-\mu \mathrm{m}$-poresize nitrocellulose membrane filters. The filters were washed twice with $5 \mathrm{ml}$ of $5 \%$ trichloroacetic acid and with $2 \mathrm{ml}$ of $95 \%$ ethanol and then placed in $10-\mathrm{ml}$ scintillation vials. These vials were incubated at room temperature for $1 \mathrm{~h}$ to dry the filters and then stored in the dark at room temperature for at least $1 \mathrm{~h}$ before liquid scintillation counting with a Beckman model LS3801 counter in which Scintiverse biodegradable cocktail was used.

The reassociation experiments always included a negative control consisting of sheared salmon sperm DNA and a positive control consisting of homologous DNA for calculating the level of hybridization. Hybridization reactions for each pair of organisms were performed in duplicate, and all hybridizations were repeated twice. Therefore, the similarity values reported below are the means of four measurements for each comparison. The reciprocal values for some of the pairs were determined and are reported separately. Dot blot hybridization was performed as described previously (42).

Preparation of rRNA. The total cellular RNAs of methanococci were isolated by phenol extraction of detergent-lysed cells as follows. A cell pellet from $2.5 \mathrm{~m}$ of an early-stationary-phase culture was obtained in a microcentrifuge tube by aerobic centrifugation at $10,000 \mathrm{rpm}$ for $15 \mathrm{~min}$ at room temperature. The pellet was resuspended in $250 \mu$ l of lysing buffer, which was composed of $8 \mathrm{M}$ urea, 50

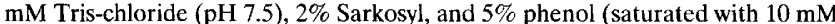
Tris-chloride [pH 7.5], $150 \mathrm{mM} \mathrm{NaCl}$, and $5 \mathrm{mM}$ disodium EDTA), and incubated at room temperature for $15 \mathrm{~min}$ with vortexing at 5 -min intervals. The RNA was purified by two extractions with phenol-chloroform $(3: 1$, vol/vol) followed by two precipitations with ethanol (as described above for DNA) to remove the phenol. The resulting pellet was washed twice with $70 \%$ ethanol, air dried at room temperature, and resuspended in $30 \mu \mathrm{l}$ of $10 \mathrm{mM}$ Tris ( $\mathrm{pH} 7.5$ ). The concentration of nucleic acids was determined by determining $A_{260}$ and $A_{280}$. The level of DNA contamination and the quality of the RNA were determined by agarose gel electrophoresis. This method yielded nucleic acid preparations, containing approximately $30 \%$ DNA (based on the intensity and location of the band), generally intact $16 \mathrm{~S}$ and $23 \mathrm{~S}$ rRNA subunits, and an $A_{260} / A_{280}$ ratio of 2.0 . The approximate concentrations of the rRNA subunits were determined by estimating the level of DNA contamination, and approximately $10 \mu \mathrm{g}$ of total RNA was used as a template for each sequencing reaction. For some samples, ribosomal pellets were prepared (32) before extraction as described above. This method yielded purer rRNA, and this rRNA was a better template for reverse transcriptase sequencing.

rRNA sequencing. The dideoxynucleotide chain termination method was used for direct $16 \mathrm{~S}$ and 23S rRNA sequencing (28). For 23S rRNA sequencing, the sequences of the primers used and the positions of the complimentary regions 
(Escherichia coli numbering; 3' of rRNA) were as follows: position $473,5^{\prime}$ CTTTCCCTCGCGGTA; position 791, 5'-ATTGGCCTTTCTCCCCT; position 1617, 5'-GTGTCGGTTCTGGGTACG: position 2591, 5'-GGTCTAAAC CCTG; and position 2760, 5'-CTTAGATGCTTTCAGC. The sequences of the $16 \mathrm{~S}$ rRNA primers used and the positions of the complimentary regions ( $E$. coli numbering as described by Brosius et al. [5]) were as follows: position 520, 5'-ACCGCGGCTGCTGGC; position 920, 5'-ATTCCTTTAAGTTTCA; and position 1400, 5'-ACGGGCGGTGTGTGC. The other 16S rRNA primers used have been described by Rouviere et al. (35).

Data analysis. Sequences were aligned by using the program "pileup" contained in Genetics Computer Group sequence analysis package V.7.01 (10) and a VAX computer. Previously published sequences of $M$. vannielii, $M$. voltaei, $M$. thermolithotrophicus, M. igneus, M. jannaschii, and Methanobacterium formicicum rRNAs were obtained from Woese et al. (47). The aligned sequences were edited to remove the gaps, and all positions that had undetermined nucleotides in any sequence were excluded from the subsequent analysis. This alignment was used in the Genetics Computer Group "distance" program for computing similarity matrices (uncorrected). Pairwise evolutionary distances were calculated with Kimura's two-parameter model (which assumes that transitions and transversions occur at different rates) by using the default transition/transversion ratio of 2 and the same alignment with the DNAdist program of the PHYLIP package, version $3.4(13,14)$. The actual transition/transversion ratio was 3.1 for the data set used. Phylogenetic trees were constructed by UPGMA, Fitch-Margoliash, neighbor-joining, parsimony, and maximum-likelihood methods contained in the PHYLIP package. A bootstrap confidence analysis was performed with the Seqboot program of the PHYLIP package by using 100 data sets (14), and consensus trees were obtained by using the Consense program. Later, the topologies of the trees constructed by the neighbor-joining and Fitch-Margoliash methods were further tested by recalculating the pairwise evolutionary distances with Kimura's two-parameter model at a transition/transversion ratio of 3 or the Jukes-Cantor correction. The tree topologies and branch lengths were nearly identical to those shown below.

Nucleotide sequence accession numbers. The GenBank accession numbers for the 16S rRNA sequences reported in this paper are as follows: " $M$. aeolicus," U39016; $M$. voltaei $\mathrm{PS}^{\mathrm{T}}$, U38461; $M$. voltaei A3, U38488; $M$. deltae $\Delta \mathrm{RC}^{\mathrm{T}}$, U38485; M. maripaludis $\mathrm{JJ}^{\mathrm{T}}$, U38484; M. maripaludis C5, U38486; M. maripaludis C6, U38487; and M. maripaludis C7, U38941. These sequences are also available from the Ribosomal Database Project, University of Illinois. The GenBank accession numbers for the partial 23S rRNA sequences are as follows: " $M$. aeolicus," U39025, U39026, U39027, and U39028; M. voltaei PS ${ }^{\mathrm{T}}$, U39017, $\mathrm{U} 39018$, U39019, and U39020; and $M$. maripaludis $\mathrm{JJ}^{\mathrm{T}}, \mathrm{U} 39021, \mathrm{U} 39022$, $\mathrm{U} 39023$, and U39024.

\section{RESULTS}

Phenotypic analysis. Previously published growth studies and $\mathrm{G}+\mathrm{C}$ content determinations indicated that the methanococcal isolates fell into two groups, those resembling $M$. maripaludis $\mathrm{JJ}^{\mathrm{T}}$ and those resembling $M$. voltaei $\mathrm{PS}^{\mathrm{T}}(45,46)$. Additional measurements of cell size supported this interpretation (Table 1). The isolates resembling $M$. maripaludis appeared to be facultative autotrophs, and growth was stimulated by amino acids and acetate. These organisms utilized L-alanine as a sole nitrogen source, and all but two strains grew with $\mathrm{N}_{2}$ as a sole nitrogen source (unpublished data). The minimum concentration of $\mathrm{NaCl}$ required for good growth was $0.1 \mathrm{M}$ for all but 3 strains, and 7 of the 16 strains grew well with a low $\mathrm{MgCl}_{2}$ concentration $(3.3 \mathrm{mM})$. The isolates resembling $M$. voltaei required leucine, isoleucine, and acetate for growth. Growth was also stimulated by pantoyl lactone and $\mathrm{Ca}^{2+}$. Alanine and $\mathrm{N}_{2}$ were not used as sole nitrogen sources. These organisms also grew poorly at $\mathrm{NaCl}$ concentrations below 0.2 $\mathrm{M}$ and, except for $M$. voltaei $\mathrm{PS}^{\mathrm{T}}$, at $\mathrm{MgCl}_{2}$ concentrations below $9.6 \mathrm{mM}$. However, given the limited nature of the measurable growth properties, it was not possible to draw firm taxonomic conclusions from these data alone.

Immunological analysis. Antisera to $M$. voltaei $\mathrm{PS}^{\mathrm{T}}, M$. maripaludis $\mathbf{J J}^{\mathbf{T}}$, and $M$. vannielii $\mathbf{S B}^{\mathbf{T}}$ cross-reacted weakly or not at all with cells of other mesophilic methanococci (Table 1). This finding was in agreement with the data of Jones et al. (24) and indicated that there was a great deal of antigenic heterogeneity. An exception to this observation was that cells of $M$. deltae and a few other strains of autotrophic methanococci reacted strongly with the $\mathrm{S}$ probe of $M$. maripaludis but showed no
TABLE 1. Immunological cross-reactivity and other properties of methanococci

\begin{tabular}{|c|c|c|c|c|c|c|}
\hline \multirow[t]{2}{*}{ Organism } & \multirow[t]{2}{*}{$\underset{(\mathrm{Gol} \%)^{a}}{\mathrm{G}+\mathrm{C} \text { content }}$} & \multirow[t]{2}{*}{$\begin{array}{l}\text { Auto- } \\
\text { troph }\end{array}$} & \multirow[t]{2}{*}{$\begin{array}{l}\text { Cell size } \\
(\mu \mathrm{m})^{b}\end{array}$} & \multicolumn{3}{|c|}{$\begin{array}{c}\text { Cross-reaction to } \\
\text { antisera } \\
\text { prepared to } \\
\text { whole cells } \\
\text { strain }^{c}:\end{array}$} \\
\hline & & & & $\mathrm{JJ}^{\mathrm{T}}$ & $\mathrm{PS}^{\mathrm{T}}$ & $\mathrm{SB}^{\mathrm{T}}$ \\
\hline \multicolumn{7}{|c|}{ M. maripaludis type } \\
\hline $\mathbf{J J}^{\mathbf{T}}$ & 33.4 & + & 1.0 & +3 & 0 & 0 \\
\hline$\Delta \mathrm{RC}^{\mathrm{T}}$ & 33.6 & + & 1.3 & +3 & 0 & 0 \\
\hline A1 & 33.7 & + & 0.9 & 0 & 0 & 0 \\
\hline A4 & 33.6 & t & 1.0 & +1 & +2 & +1 \\
\hline A5 & 33.9 & + & 1.1 & 0 & 0 & 0 \\
\hline $\mathrm{C} 5$ & 33.1 & + & 1.2 & +1 & 0 & 0 \\
\hline $\mathrm{C} 8$ & 33.9 & + & 1.1 & +1 & 0 & 0 \\
\hline C9 & 33.6 & + & 1.1 & 0 & 0 & 0 \\
\hline $\mathrm{C} 10$ & 33.4 & + & 1.0 & +3 & 0 & 0 \\
\hline $\mathrm{C} 11$ & 33.5 & + & 1.0 & +1 & 0 & 0 \\
\hline $\mathrm{C} 12$ & 33.4 & + & 1.0 & 0 & 0 & 0 \\
\hline $\mathrm{C} 13$ & 32.6 & + & 0.9 & +2 & 0 & 0 \\
\hline $\mathrm{C} 14$ & 33.6 & + & 1.0 & 0 & 0 & 0 \\
\hline D1 & 33.4 & + & 1.0 & +2 & 0 & 0 \\
\hline S1 & 33.2 & + & 0.9 & 0 & 0 & 0 \\
\hline S2 & 34.4 & + & 1.1 & 0 & 0 & +1 \\
\hline \multicolumn{7}{|l|}{ M. voltaei type } \\
\hline $\mathrm{PS}^{\mathrm{T}}$ & 29.6 & - & 1.6 & +1 & +4 & 0 \\
\hline A2 & 29.3 & - & 1.4 & +1 & +2 & 0 \\
\hline A3 & 29.3 & - & 1.5 & +1 & +3 & 0 \\
\hline $\mathrm{C} 1$ & 29.5 & - & 1.7 & 0 & 0 & 0 \\
\hline $\mathrm{C} 2$ & 29.6 & - & 1.3 & 0 & 0 & 0 \\
\hline $\mathrm{C} 3$ & 29.8 & - & 1.4 & 0 & +1 & 0 \\
\hline $\mathrm{C} 4$ & 31.5 & - & 1.4 & 0 & +1 & 0 \\
\hline \multicolumn{7}{|l|}{ Other species } \\
\hline "M. aeolicus" & 32 & + & 1.7 & +2 & +1 & 0 \\
\hline $\mathrm{SB}^{\mathrm{T}}$ & 32.5 & + & 1.3 & +1 & 0 & +4 \\
\hline
\end{tabular}

${ }^{a}$ Data from reference 44

${ }^{b}$ Sizes are arithmetic averages. The standard deviation was $0.2 \mu \mathrm{m}$ for 50 measurements of each strain.

${ }^{c}$ The cross-reactions ranged from homologous cross-reactions $(+4)$ to very faint cross-reactions $(+1)$ to no visible cross-reaction $(0)$.

immunological cross-reactivity with $M$. voltaei and $M$. vannielii antisera, indicating that there is a close antigenic relationship between $M$. deltae and $M$. maripaludis. This reaction was consistent with the genetic similarity of these strains to $M$. maripaludis (see below).

Cellular protein analysis. Polyacrylamide gel electrophoresis (PAGE) of cellular proteins under denaturing conditions has been recognized as a valuable taxonomic tool at the species level $(19,25)$. The mesophilic methanococcal species can also be distinguished by this technique (44). Therefore, the wholecell proteins of 22 mesophilic isolates were compared by SDSPAGE (Fig. 1 and data not shown). The overall similarity of the protein profiles of 6 isolates to $M$. voltaei and of 16 isolates to $M$. maripaludis was evident when this technique was used, and the patterns of the two groups were quite distinct from each other. The differences among the methanococcal species and the isolates were quantified by identifying the number of dissimilar bands in pairwise comparisons. A dendrogram based on similarity values divided the isolates into two clusters (Fig. 2). These results were consistent with the nutritional properties and $\mathrm{G}+\mathrm{C}$ contents of the organisms (Table 1) (45). Within each cluster, two subclusters were identified. On the autotrophic branch, isolates $\mathrm{C} 5, \mathrm{C} 6, \mathrm{C} 7$, and $\mathrm{C} 8$ comprised one sub- 


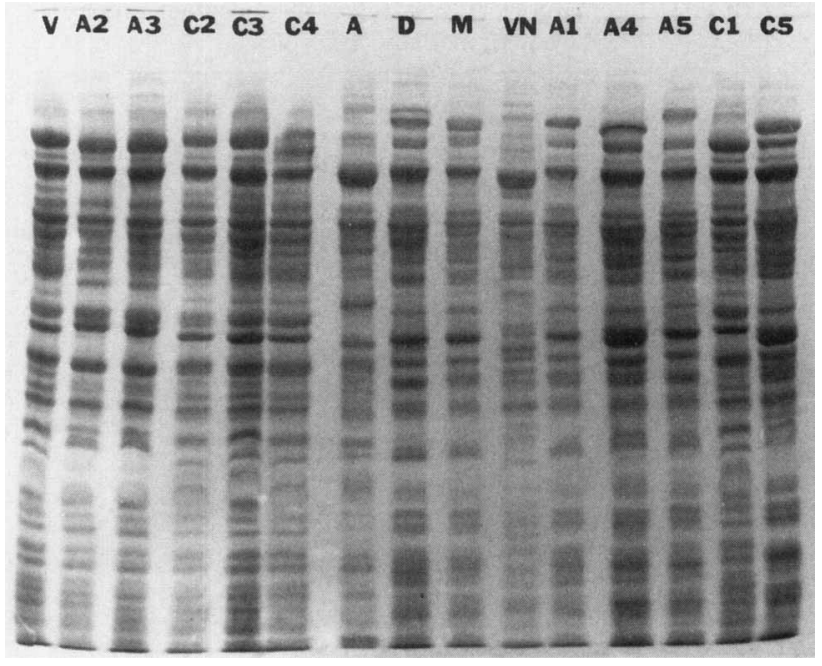

FIG. 1. Electrophoretic analysis of cellular proteins of mesophilic methanococci. Lane V, $M$. voltaei $\mathrm{PS}^{\mathrm{T}}$; lanes A2, A3, C2, C3, C4, and C1, various heterotrophic isolates; lane $\mathrm{A}$, " $M$. aeolicus;" lane $\mathrm{D}, M$. deltae $\Delta \mathrm{RC}$; lane $\mathrm{M}, M$. maripaludis $\mathrm{JJ}^{\mathrm{T}}$; lane $\mathrm{VN}, M$. vannielii $\mathrm{SB}^{\mathrm{T}}$; lanes $\mathrm{A} 1, \mathrm{~A} 4, \mathrm{~A} 5$, and $\mathrm{C} 5$, various autotrophic isolates.

cluster, which exhibited a level of relatedness to the second subcluster of approximately $62 \%$. The second subcluster included the type strains of $M$. maripaludis and $M$. deltae and the remaining autotrophic isolates. Similarly, isolates A2 and A3 made up one subcluster on the heterotrophic branch; the level of relatedness between this subcluster and the other isolates and type strain of $M$. voltaei was $55 \%$.

DNA relatedness. The results of DNA-DNA hybridization studies performed with the type strains of all of the methanococcal species except $M$. deltae indicated that the levels of DNA relatedness for all pairs were less than $35 \%$ (Table 2). When UPGMA was used, the highest relatedness value, $30 \%$ (mean of reciprocal measurements), was obtained with $M$. maripaludis and $M$. vannielii. $M$. voltaei was related to this

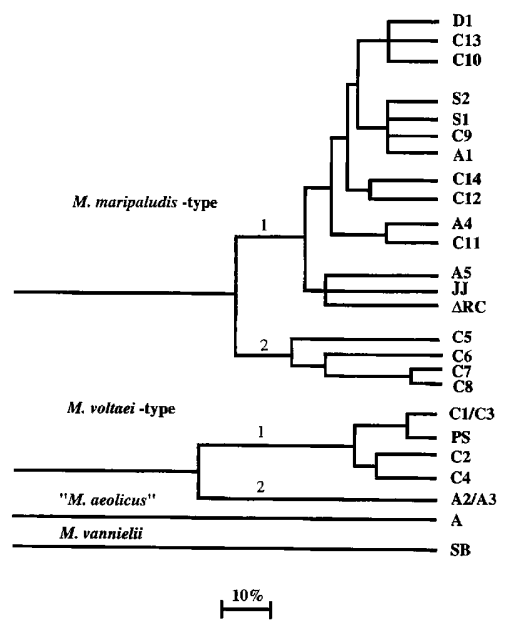

FIG. 2. Dendrogram based on similarity values obtained from cellular protein electrophoretic analysis of mesophilic methanococci. Clustering was accomplished by using UPGMA. Most of the organisms are indicated by their strain designations; the only exception is " $M$. aeolicus," which is indicated by A. The type strains used were $M$. maripaludis $\mathrm{JJ}, M$. deltae $\triangle \mathrm{RC}, M$. voltaei $\mathrm{PS}$, and $M$. vannielii $\mathrm{SB}$. For lineages that are not joined, the level of similarity was less than $50 \%$. group at a mean value of $15 \%$. Finally, " $M$. aeolicus" was related to the other three species at a mean value of $11 \%$. The low levels of DNA relatedness within the genus Methanococcus illustrated the considerable genetic diversity of the mesophilic methanococci.

Levels of DNA relatedness between heterotrophic isolates were determined by solution hybridization and dot blot procedures. In the solution hybridization experiments in which $M$. voltaei $\mathrm{PS}^{\mathrm{T}}$ was used as the probe, the levels of hybridization (mean \pm standard deviation; $n=4$ ) were $92 \% \pm 3 \%, 91 \% \pm$ $4 \%, 89 \% \pm 1 \%, 87 \% \pm 2 \%$, and $38 \% \pm 3 \%$ for strains $\mathrm{C} 1, \mathrm{C} 2$, C3, C4, and A3, respectively. When the dot blot method was used with $M$. voltaei $\mathrm{PS}^{\mathrm{T}}$ as the probe, the levels of hybridization were $90 \% \pm 6 \%, 88 \% \pm 5 \%, 77 \% \pm 1 \%, 61 \% \pm 5 \%, 21 \%$ $\pm 3 \%, 15 \% \pm 0 \%, 6 \% \pm 0 \%, 4 \% \pm 0 \%$, and $7 \% \pm 3 \%$ for strains $\mathrm{C} 1, \mathrm{C} 2, \mathrm{C} 3, \mathrm{C} 4, \mathrm{~A} 2$, and $\mathrm{A} 3, M$. maripaludis $\mathrm{JJ}^{\mathrm{T}}, M$. vannielii $\mathrm{SB}^{\mathrm{T}}$, and " $M$. aeolicus," respectively. In the solution hybridization experiments in which strain A3 was used as the probe, the levels of hybridization were $37 \% \pm 4 \%, 33 \% \pm 2 \%$, and $69 \% \pm 4 \%$ for strains $\mathrm{C} 2, \mathrm{C} 4$, and $\mathrm{A} 2$, respectively. DNA from strain A3 also hybridized weakly to DNAs from the type strains of the autotrophic methanococci (Table 2). Thus, both methods grouped the isolates into the same clusters identified by cellular protein analysis. Similarly, when strain A3 genomic DNA was used as a probe, the close relationship between strains A2 and A3 was confirmed.

Because of the large number of autotrophic isolates, an initial survey of their levels of relatedness was performed by the dot blot procedure (Table 3). DNA hybridization studies performed with $M$. maripaludis $\mathbf{J J}^{\mathbf{T}}$ and $M$. deltae $\Delta \mathrm{RC}^{\mathrm{T}}$ genomic DNAs as the probes revealed that there were two groups. Both of these probes exhibited low levels of DNA relatedness with isolates $\mathrm{C} 5, \mathrm{C} 6, \mathrm{C} 7$, and $\mathrm{C} 8$ and high levels of DNA relatedness with the rest of the isolates. Therefore, C5, C6, and $\mathrm{C} 7$ genomic DNAs were also used as probes to determine the levels of DNA relatedness of these isolates. The levels of DNA relatedness of strains C5, C6, and C7 were slightly higher with each other and with $\mathrm{C} 8$ than with the other autotrophic strains, suggesting that $\mathrm{C} 5, \mathrm{C} 6, \mathrm{C} 7$, and $\mathrm{C} 8$ were related to each other but not to the other strains. In addition, high levels of relatedness were obtained for strains $\mathrm{C} 7$ and $\mathrm{C} 8$, suggesting that these two isolates were very similar.

These conclusions were confirmed by using the solution hybridization procedure. $M$. maripaludis $\mathrm{JJ}^{\mathrm{T}}$ exhibited a higher level of DNA relatedness to $M$. deltae $\Delta \mathrm{RC}^{\mathrm{T}}$ than to isolates $\mathrm{C} 5, \mathrm{C} 6$, and $\mathrm{C} 7$ (Table 2). In addition, isolates $\mathrm{C} 12, \mathrm{C} 13, \mathrm{~S} 1$, D1, C9, and A4 exhibited levels of DNA relatedness to $M$. maripaludis $\mathrm{JJ}^{\mathrm{T}}$ of $86,106,89,96,87$, and $88 \%$ respectively. For these isolates, reciprocal hybridization experiments were not performed.

Although the results of the solution hybridization experiments performed with S1 nuclease were in qualitative agreement with the dot blot hybridization results, the latter procedure consistently underestimated the levels of DNA relatedness. For strains that were not closely related, the level of DNA relatedness was frequently much lower as determined by the dot blot procedure, even though the relative order of the strains was the same. Both procedures identified the subcluster containing strains $\mathrm{C} 5, \mathrm{C} 6, \mathrm{C} 7$, and $\mathrm{C} 8$ among the autotrophic isolates and the subcluster containing strains A2 and A3 among the heterotrophic isolates. However, in both cases the results of the dot blot procedure suggested that the level of DNA relatedness was only one-fourth to one-third the level of relatedness found with the solution hybridization method. Therefore, the dot blot procedure did not yield results equiv- 
TABLE 2. Levels of DNA relatedness for the type strains and some reference strains of the methanococcal species as determined by solution hybridization

\begin{tabular}{|c|c|c|c|c|c|c|c|c|}
\hline \multirow{2}{*}{$\begin{array}{c}\text { Source of unlabeled } \\
\text { DNA }\end{array}$} & \multicolumn{8}{|c|}{$\%$ Hybridization with ${ }^{35}$ S-labeled DNA from ${ }^{a}$ : } \\
\hline & $\begin{array}{l}\text { Strain } \\
\text { PS }^{T}\end{array}$ & $\begin{array}{c}\text { Strain } \\
\text { A3 }\end{array}$ & $\begin{array}{c}\text { "M. } \\
\text { aeolicus" }\end{array}$ & $\begin{array}{l}\text { Strain } \\
\text { SB }^{T}\end{array}$ & $\begin{array}{c}\text { Strain } \\
\mathbf{J J}^{T}\end{array}$ & $\begin{array}{l}\text { Strain } \\
\text { C5 }\end{array}$ & $\begin{array}{l}\text { Strain } \\
\text { C6 }\end{array}$ & $\begin{array}{l}\text { Strain } \\
\text { C7 }\end{array}$ \\
\hline M. voltaei $\mathrm{PS}^{\mathrm{T}}$ & $100^{b}$ & $35 \pm 2$ & $3 \pm 1$ & $5 \pm 7$ & $14 \pm 4$ & $-^{c}$ & - & - \\
\hline "M. aeolicus" & $6 \pm 6$ & $24 \pm 9$ & 100 & $22 \pm 4$ & $13 \pm 4$ & - & - & - \\
\hline M. vannielii $\mathrm{SB}^{\mathrm{T}}$ & $12 \pm 2$ & $4 \pm 13$ & $15 \pm 2$ & 100 & $33 \pm 0$ & $17 \pm 3$ & $27 \pm 3$ & $32 \pm 11$ \\
\hline M. maripaludis $\mathrm{JJ}^{\mathrm{T}}$ & $30 \pm 5$ & $19 \pm 5$ & $4 \pm 2$ & $27 \pm 8$ & 100 & $56 \pm 4$ & $54 \pm 2$ & $54 \pm 4$ \\
\hline$M$. deltae $\Delta \mathrm{RC}^{\mathrm{T}}$ & $18 \pm 5$ & - & - & $31 \pm 1$ & $83 \pm 2$ & - & - & $53 \pm 2$ \\
\hline M. maripaludis $\mathrm{C} 5$ & - & - & - & - & $67 \pm 5$ & 100 & $64 \pm 5$ & $65 \pm 2$ \\
\hline M. maripaludis $\mathrm{C} 6$ & - & - & - & - & $61 \pm 2$ & $69 \pm 4$ & 100 & $66 \pm 2$ \\
\hline M. maripaludis $\mathrm{C} 7$ & - & - & - & - & $69 \pm 1$ & $69 \pm 4$ & $81 \pm 2$ & 100 \\
\hline
\end{tabular}

${ }^{a}$ Values are arithmetic means \pm standard deviations $(n=4)$.

${ }^{b}$ A value of $100 \%$ indicates that the DNAs were homologous.

$c$ - not determined.

alent to the results obtained with other DNA hybridization methods.

RNA sequence analysis. Nearly complete $16 \mathrm{~S}$ rRNA sequences (about 1,415 nucleotide positions) were obtained for " $M$. aeolicus," $M$. voltaei $\mathrm{PS}^{\mathrm{T}}, M$. deltae $\Delta \mathrm{RC}^{\mathrm{T}}, M$. maripaludis $\mathrm{JJ}^{\mathrm{T}}$, and isolates A3, C5, C6, and C7. These sequences and the previously published sequences of $M$. vannielii $\mathrm{SB}^{\mathrm{T}}, M$. thermolithotrophicus $\mathrm{SN} 1^{\mathrm{T}}, M$. igneus $\mathrm{Kol}^{\mathrm{T}}, M$. jannaschii JAL-1 ${ }^{\mathrm{T}}$, and Methanobacterium formicicum $\mathrm{MF}^{\mathrm{T}}$ were aligned, and the levels of sequence similarity were calculated. The sequences of the mesophilic methanococci were consistent with the sequence signatures obtained for members of the Methanococcales except for substitution of a $G$ at position 392 for a $\mathrm{U}$ in $M$. voltaei $\mathrm{PS}^{\mathrm{T}}$ (35). Similarity values ranging from 91.8 to $96.2 \%$ for the 16S rRNA sequences of $M$. vannielii $\mathrm{SB}^{\mathrm{T}}$, "M. aeolicus," $M$. voltaei $\mathrm{PS}^{\mathrm{T}}$, and $M$. maripaludis $\mathrm{JJ}^{\mathrm{T}}$ supported the taxonomic relationship of these organisms at the genus level. In contrast, the levels of sequence similarity for strain A 3 and $M$. voltaei $\mathrm{PS}^{\mathrm{T}}(99.18 \%)$ and for $M$. deltae $\Delta \mathrm{RC}^{\mathrm{T}}$, strains C5, C6, and $\mathrm{C} 7$, and $M$. maripaludis $\mathrm{JJ}^{\mathrm{T}}(99.29$ to $99.86 \%)$ were much higher.
A phylogenetic tree was constructed by the method of Fitch and Margoliash (15), using the evolutionary distances computed from the aligned sequences to show the relationships among members of the Methanococcales (Fig. 3). A discrete cluster containing $M$. maripaludis $\mathrm{JJ}^{\mathrm{T}}, M$. vannielii $\mathrm{SB}^{\mathrm{T}}$, and $M$. deltae $\triangle \mathrm{RC}^{\mathrm{T}}$ was formed. These results were corroborated by the results of a bootstrap analysis (Fig. 3) and were similar to the results of neighbor-joining, DNA parsimony, and maximum-likelihood analyses (data not shown). M. vannielii $\mathrm{SB}^{\mathrm{T}}$ clustered with $M$. maripaludis $\mathrm{JJ}^{\mathbf{T}}$ and $M$. deltae $\Delta \mathrm{RC}^{\mathbf{T}}$ in 73 to 94\% of the replicates, depending on the choice of outgroups (data not shown).

Although the major cluster on the autotrophic branch was strongly supported by bootstrap analysis, the branching order of strains C5, C6, and C7 depended on the algorithm used. The bootstrap analysis only weakly supported the branching order in Fig. 3, which was different from the branching order obtained by the cellular protein analysis (Fig. 2). The numbers of nucleotide differences between strains $\mathrm{C} 5$ and $\mathrm{C} 6$, between strains $\mathrm{C} 5$ and $\mathrm{C} 7$, and between strains $\mathrm{C} 6$ and $\mathrm{C} 7$ were four,

TABLE 3. Levels of DNA relatedness between autotrophic isolates as determined by dot blot hybridization

\begin{tabular}{|c|c|c|c|c|c|}
\hline \multirow{2}{*}{$\begin{array}{c}\text { Source of unlabeled } \\
\text { DNA }\end{array}$} & \multicolumn{5}{|c|}{$\%$ Hybridization with ${ }^{35}$ S-labeled DNA from strain $^{a}$ : } \\
\hline & $\mathrm{JJ}^{\mathrm{T}}$ & $\Delta \mathrm{RC}^{\mathrm{T}}$ & $\mathrm{C} 5$ & C6 & $\mathrm{C} 7$ \\
\hline$J J^{T}$ & $100^{b}$ & $42 \pm 1$ & $13 \pm 1$ & $12 \pm 1$ & $24 \pm 1$ \\
\hline$\Delta \mathrm{RC}^{\mathrm{T}}$ & $41 \pm 2$ & 100 & $16 \pm 4$ & $16 \pm 0$ & $26 \pm 1$ \\
\hline $\mathrm{A} 1$ & $39 \pm 1$ & $36 \pm 10$ & $15 \pm 9$ & $14 \pm 2$ & $28 \pm 3$ \\
\hline A4 & $48 \pm 1$ & $30 \pm 5$ & $14 \pm 5$ & $14 \pm 1$ & $28 \pm 8$ \\
\hline A5 & $29 \pm 1$ & $64 \pm 2$ & $13 \pm 2$ & $15 \pm 1$ & $28 \pm 9$ \\
\hline $\mathrm{C} 9$ & $43 \pm 1$ & $36 \pm 3$ & $15 \pm 2$ & $12 \pm 2$ & $26 \pm 5$ \\
\hline $\mathrm{C} 10$ & $46 \pm 1$ & $30 \pm 4$ & $18 \pm 2$ & $16 \pm 2$ & $29 \pm 1$ \\
\hline $\mathrm{C} 11$ & $44 \pm 1$ & $30 \pm 3$ & $12 \pm 1$ & $12 \pm 2$ & $25 \pm 1$ \\
\hline $\mathrm{C} 12$ & $47 \pm 2$ & $53 \pm 6$ & $15 \pm 2$ & $18 \pm 4$ & $27 \pm 9$ \\
\hline $\mathrm{C} 13$ & $85 \pm 1$ & $37 \pm 8$ & $14 \pm 1$ & $18 \pm 3$ & $30 \pm 4$ \\
\hline $\mathrm{C} 14$ & $48 \pm 1$ & $32 \pm 5$ & $18 \pm 3$ & $13 \pm 3$ & $24 \pm 1$ \\
\hline D1 & $66 \pm 3$ & $37 \pm 1$ & $12 \pm 1$ & $13 \pm 2$ & $28 \pm 1$ \\
\hline S1 & $31 \pm 1$ & $34 \pm 4$ & $14 \pm 3$ & $12 \pm 1$ & $33 \pm 2$ \\
\hline S2 & $33 \pm 1$ & $61 \pm 2$ & $12 \pm 1$ & $12 \pm 1$ & $27 \pm 1$ \\
\hline C5 & $16 \pm 2$ & $16 \pm 1$ & 100 & $18 \pm 1$ & $30 \pm 3$ \\
\hline C6 & $17 \pm 3$ & $16 \pm 0$ & $23 \pm 1$ & 100 & $39 \pm 2$ \\
\hline $\mathrm{C} 7$ & $14 \pm 2$ & $14 \pm 0$ & $20 \pm 3$ & $23 \pm 4$ & 100 \\
\hline $\mathrm{C} 8$ & $14 \pm 3$ & $12 \pm 1$ & $19 \pm 5$ & $22 \pm 3$ & $99 \pm 1$ \\
\hline
\end{tabular}

${ }^{a}$ Values are the arithmetic means \pm standard deviations $(n=4)$ obtained with two separate ${ }^{35}$ S-labeled DNA preparations, and each assay was performed in duplicate.

${ }^{b}$ A value of $100 \%$ indicates homologous hybridization. 


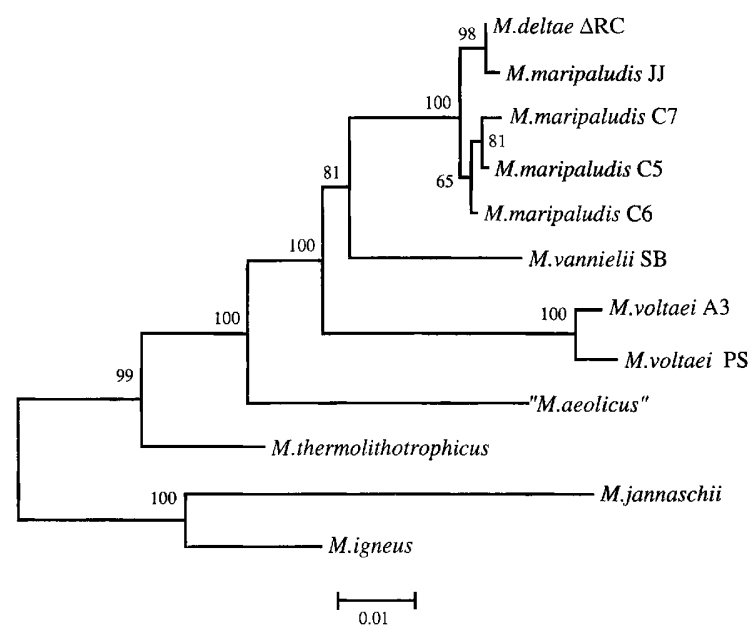

FIG. 3. Phylogenetic tree showing the relationships among the mesophilic methanococcal species and isolates $\mathrm{A} 3, \mathrm{C} 5, \mathrm{C} 6$, and $\mathrm{C} 7$ based on 16S rRNA sequences. The dendrogram was constructed by using the method of Fitch and Margoliash (15) contained in the PHYLIP phylogeny inference package. The tree was rooted by reference to Methanobacterium formicicum, a distant relative of the Methanococcales. Scale bar $=0.01$ estimated substitution per nucleotide site. The numbers at the branch points are the percentages of bootstrap replicates in which the clusters were found.

six, and five, respectively. The small numbers of substitutions may explain why the branching order was ambiguous.

$M$. voltaei formed a monophyletic group with $M$. maripaludis and $M$. vannielii, indicating that these organisms had a common line of descent. In the bootstrap analysis, this cluster occurred in $100 \%$ of the replicates. In addition, it was formed consistently, irrespective of the outgroup sequences that were used to root the tree. The levels of DNA hybridization (30 and $12 \%$, respectively) and $16 \mathrm{~S}$ rRNA sequence similarity (94.1 and $93.9 \%$, respectively) when $M$. voltaei was compared with $M$. maripaludis and $M$. vannielii were consistent with the taxonomic relationship of these organisms at the genus level. The phenotypic characteristics of the mesophilic strains further supported the distinction of $M$. voltaei and $M$. maripaludis (45, 46).

"M. aeolicus" emerged as the most distantly related mesophilic methanococcus. This lineage appeared to be the deepest branch among the mesophilic methanococci on the trees obtained by the Fitch-Margoliash method (Fig. 3) and by neighbor-joining methods (data not shown). A total of 14 unique nucleotide substitutions not found in any other member of the Methanococcales supported this conclusion. The results of DNA hybridization also supported the deep divergence of this lineage.

The cluster composed of "M. aeolicus," $M$. voltaei, $M$. maripaludis, and $M$. vannielii was unstable to variation in outgroup sequences. When the sequence of $M$. thermolithotrophicus was the only outgroup, the distance-based methods could not resolve the position of " $M$. aeolicus" clearly, and the characterbased (maximum-likelihood) method clustered "M. aeolicus" with the outgroup, $M$. thermolithotrophicus (data not shown). This clustering was probably an artificial clustering that occurred because of the limited number of sequences analyzed $(12,33)$. Phylogenetic trees derived from both distance matrix methods (the neighbor-joining and Fitch-Margoliash methods) and character-based methods (the maximum-likelihood and DNA parsimony methods) resolved the position of " $M$. aeolicus" clearly when $M$. igneus, $M$. jannaschii, Methanobacterium
TABLE 4. Levels of partial 23S rRNA sequence similarity for mesophilic methanococcal species

\begin{tabular}{lrccc}
\hline \multirow{2}{*}{ Organism } & \multicolumn{4}{c}{ \% 23S rRNA Similarity or no. of differences } \\
\cline { 2 - 5 } & "M. aeolicus" & M. voltaei & M. maripaludis & M. vannielii \\
\hline "M. aeolicus" & & 85.9 & 91.3 & 91.3 \\
M. voltaei $\mathrm{PS}^{\mathrm{T}}$ & $107 / 761$ & & 88.7 & 88.9 \\
M. maripaludis $\mathrm{JJ}^{\mathrm{T}}$ & $72 / 824$ & $88 / 780$ & & 98.0 \\
M. vannielii $\mathrm{SB}^{\mathrm{T}}$ & $79 / 911$ & $95 / 854$ & $18 / 922$ & \\
\hline
\end{tabular}

${ }^{a}$ The values on the upper right are the percentages of similarity obtained for partial 23S rRNA sequences, and the values on the lower left are the number of observed differences (substitutions and deletions)/number of nucleotide positions compared.

formicicum, and $M$. thermolithotrophicus were used as outgroups. The results of a bootstrap analysis further supported the clustering of " $M$. aeolicus" with $M$. voltaei, $M$. maripaludis, and $M$. vannielii, and this grouping appeared in $100 \%$ of the replicates.

Differences in the $\mathrm{G}+\mathrm{C}$ contents of the $16 \mathrm{~S}$ rRNAs could introduce biases into the phylogenetic analyses. Within the mesophilic methanococci and $M$. thermolithotrophicus, such bias was not a concern because the $\mathrm{G}+\mathrm{C}$ contents were nearly identical and ranged from 55.2 to $58.5 \mathrm{~mol} \%$. However, the $\mathrm{G}+\mathrm{C}$ contents of $M$. igneus and $M$. jannaschii rRNAs were 62.5 and $63.9 \mathrm{~mol} \%$, respectively. To minimize possible compositional biases, the phylogenetic analyses were confined to transversions only (6). In these analyses, the mesophilic methanococci and $M$. thermolithotrophicus remained a monophyletic group (data not shown). However, $M$. igneus was associated with this group, and the root of the Methanococcales was between $M$. igneus and $M$. jannaschii. This result is identical to the result obtained by Burggraf et al. (6) when fewer sequences of mesophilic methanococci were available.

In some bacterial groups, the phylogenies derived from rRNA sequence analyses may be wrong because of genetic crossover events within the sequences (38). This potential source of error was examined by analyzing the cophenetic correlation coefficient of the UPGMA clustering data (39). In this analysis, a high cophenetic correlation coefficient supports a good ultrametric relationship among the sequences and argues against this type of error. Within the mesophilic methanococcal sequences, the cophenetic correlation coefficient was 0.96 . Thus, it was unlikely that genetic crossover events occurred in these sequences.

The close association of $M$. maripaludis with $M$. vannielii was further confirmed by comparing portions of the 23S rRNA sequences (Table 4). The low similarity values for $M$. voltaei and " $M$. aeolicus" further emphasized the deep divergence of this group. However, because of the lack of suitable outgroups, a more detailed analysis was not performed.

To determine the heterogeneity of the rRNAs within a species, portions of the $16 \mathrm{~S}$ and $23 \mathrm{~S}$ rRNAs of most of the isolates were sequenced. The regions chosen represented conserved and variable regions. For instance, in the comparison of $M$. voltaei and $M$. vannielii, the levels of substitution in the regions sequenced by $16 \mathrm{~S}$ rRNA primers 520,920 , and 1400 were 7.6 , 7.3 , and $2.9 \%$, respectively. For $23 \mathrm{~S}$ rRNA primers 473,791 , 1617 , and 2760 , the levels of substitution were $12.3,10.4,19.7$, and $0.9 \%$, respectively. Thus, primers 1400 and 473 were chosen to represent conserved and variable regions, respectively.

Of the strains closely related to $M$. voltaei $\mathrm{PS}^{\mathrm{T}}$, only isolate $\mathrm{C} 2$ contained substitutions in the conserved region adjacent to primer 1400 (Table 5). For the more variable region adjacent 
TABLE 5. Substitutions or deletions compared with the type strains found in the partial sequences of $16 \mathrm{~S}$ and $23 \mathrm{~S}$ rRNAs of the methanococcal isolates

\begin{tabular}{|c|c|c|}
\hline \multirow[b]{2}{*}{ Strain(s) } & \multicolumn{2}{|c|}{ Substitution(s) and deletion ${ }^{a}$} \\
\hline & $\begin{array}{l}\text { Primer } 1400 \\
(16 \mathrm{~S} \text { rRNA })^{b}\end{array}$ & $\begin{array}{c}\text { Primer } 473 \\
(23 S \text { rRNA })^{c}\end{array}$ \\
\hline
\end{tabular}

\begin{tabular}{lll}
\hline M. voltaei $\mathrm{PS}^{\mathrm{T}}$ & & \\
$\mathrm{C} 1$ & 0 & $\mathrm{U}_{265} \rightarrow \mathrm{G}$ \\
$\mathrm{C} 2$ & $\mathrm{G}_{1148} \rightarrow \mathrm{U}, \mathrm{G}_{1125} \rightarrow \mathrm{U}$ & $\mathrm{U}_{265} \rightarrow \mathrm{G}$ \\
$\mathrm{C} 3$ & $\mathrm{ND}^{d}$ & $\mathrm{U}_{265} \rightarrow \mathrm{G}$ \\
$\mathrm{C} 4$ & 0 & $\mathrm{U}_{265} \rightarrow \mathrm{G}, \mathrm{A}_{285} \rightarrow \mathrm{U}$ \\
$\mathrm{A} 3$ & 0 & $\mathrm{U}_{265} \rightarrow \mathrm{G}, \mathrm{A}_{289} \rightarrow \mathrm{C}, \mathrm{U}_{340} \rightarrow$ deletion
\end{tabular}

M. maripaludis $\mathrm{JJ}^{\mathrm{T}}$

$\begin{array}{lll}\Delta \mathrm{RC}^{\mathrm{T}}, \mathrm{A} 5, \mathrm{C} 12, \mathrm{C} 13, \mathrm{C} 5 & 0 & 0 \\ \mathrm{C} 6 & 0 & \mathrm{~A}_{368} \rightarrow \mathrm{C} \\ \mathrm{C} 7 & 0 & \mathrm{U}_{279} \rightarrow \mathrm{C}, \mathrm{G}_{275} \rightarrow \mathrm{A}, \mathrm{A}_{270} \rightarrow \mathrm{G} \\ \mathrm{S} 1 & 0 & \mathrm{U}_{325} \rightarrow \mathrm{A}, \mathrm{G}_{275} \rightarrow \mathrm{A}, \mathrm{A}_{270} \rightarrow \mathrm{G}, \mathrm{C}_{374} \rightarrow \mathrm{U} \\ \mathrm{C} 9, \mathrm{C} 11, \mathrm{~A} 4 & 0 & \mathrm{U}_{325} \rightarrow \mathrm{A}, \mathrm{G}_{27}\end{array}$

${ }^{a}$ The numbering used was the M. vannielli $16 \mathrm{~S}$ and $23 \mathrm{~S}$ rRNA sequence numbering of Jarsch and Bock $(20,21)$.

${ }^{b}$ Approximately 200 nucleotide positions were compared.

${ }^{c}$ A total of 163 to 265 nucleotide positions were compared.

${ }^{d} \mathrm{ND}$, not determined.

to primer 473 in the $23 \mathrm{~S}$ rRNA, isolate A3 contained two substitutions and one deletion compared with the type strain. Similarly, for the autotrophic isolates related to $M$. maripaludis $\mathrm{JJ}^{\mathrm{T}}$, no substitutions were detected near primer 1400 . However, some isolates contained as many as four substitutions near primer 473 . None of these changes disrupted the predicted secondary structures of $M$. vannielii $16 \mathrm{~S}$ and $23 \mathrm{~S}$ rRNAs $(20,21)$. In addition, some of the substitutions were found in more than one strain, indicating that they were unlikely to be sequencing artifacts. Importantly, the distribution of the substitutions was not correlated with other measures of relatedness. For instance, as determined by DNA relatedness and cellular protein patterns, strain $\mathrm{C} 2$ was closely related to $M$. voltaei $\mathrm{PS}^{\mathrm{T}}$, yet $\mathrm{C} 2$ had the most substitutions in the primer 1400 region. Likewise, the levels of DNA relatedness of isolates $\mathrm{C} 9$ and $\mathrm{A} 4$ to $M$. maripaludis $\mathrm{JJ}^{\mathrm{T}}$ were 87 to $88 \%$, but these strains had the most substitutions in the primer 473 region. In contrast, no substitutions were found in this region in isolate C5, which exhibited only $62 \%$ DNA relatedness to $M$. maripaludis $\mathbf{J J}^{\mathrm{T}}$.

\section{DISCUSSION}

The results of phylogenetic and taxonomic analyses of cellular protein patterns, DNA relatedness, and nearly complete $16 \mathrm{~S}$ rRNA sequences were in general agreement. All three methods clearly identified close relationships between $M$. voltaei and isolate A3 and among $M$. maripaludis, $M$. deltae, and isolates $\mathrm{C} 5, \mathrm{C} 6$, and $\mathrm{C} 7$. However, the methods were most useful for different phylogenetic depths. The cellular protein analysis and DNA relatedness methods were especially useful for distinguishing closely related strains. Sequencing of rRNA revealed deeper phylogenetic relationships but did not accurately distinguish relationships at the species and subspecies levels. Similar observations have been made by other workers for various eubacterial genera $(1,16,30,40,41)$, and the incongruity of the results of rRNA sequence analysis of closely related bacterial groups with the results of other taxonomic methods appears to be a frequent observation.

Three possible explanations for the inability of rRNA sequencing to determine phylogenetic relationships among closely related strains were explored with the methanococci.
These explanations fall into the following three general categories: genetic recombination within the rRNA sequences, low resolution because of high levels of similarity of the sequences, and discrepancies between gene trees and organismal trees within bacterial populations.

For the genus Aeromonas, it has been proposed that genetic crossover events within the rRNA genes result in poor agreement between rRNA sequence comparisons and DNA relatedness data (38). However, a high cophenetic correlation coefficient for the methanococcal sequences indicated that the ultrametric relationship was good. Therefore, genetic crossover events were unlikely.

The second possible explanation follows from statistical considerations of rRNA sequencing data. The relationship between level of rRNA sequence similarity and level of DNA relatedness is a logarithmic function in which the level of sequence similarity within a species $(>70 \%$ DNA relatedness) is expected to be greater than $98 \%$ (11). At high levels of similarity, the resolution of the rRNA sequencing method is low because only a small number of substitutions is observed. Thus, the relative standard error for determining the substitution rate during evolution from the observed similarity values is expected to be high (26). For instance, for a 1,400-bp sequence, the relative standard errors at levels of sequence similarity of $99.5,99,98,95$, and $90 \%$ are estimated to be 38,27 , 19,12 , and $8 \%$, respectively (26). The high level of uncertainty in determining the substitution rate implies that the rRNAbased trees for closely related organisms will be very inaccurate, and poor agreement between rRNA-based trees and trees obtained by other methods is expected. The ambiguity of the branching order on the rRNA-based tree for isolates $\mathrm{C} 5, \mathrm{C} 6$, and $C 7$ was probably due to this cause. Within this group, the levels of rRNA sequence similarity range from 99.58 to $99.72 \%$, and the relative error in estimating the substitution rate is high, $>38 \%$. Not surprisingly, the topology of the rRNA-based tree is not strongly supported by bootstrapping and differs from the topology of the tree based on cellular protein patterns.

Lastly, rRNA sequence analysis produces a gene tree, and differences between gene trees and organismal trees derived from classical methods are well recognized in eukaryotic biology (2). In prokaryotes, it is also likely that gene trees and 
organismal trees differ under certain circumstances, even in the absence of significant genetic exchange between strains. For instance, because the population size of most bacterial species vastly exceeds the mutation frequency, the allelic diversity or sequence heterogeneity within a population or species can be considerable. The variability of the methanococcal isolates in their $16 \mathrm{~S}$ and $23 \mathrm{~S}$ rRNA partial sequences clearly demonstrates that there is variability between strains that exhibit high levels of DNA relatedness, even in the sequences of very conserved molecules like rRNAs. For instance, strain C2, which contains two substitutions near primer 1400 of the 16S rRNA, was obtained from the same salt marsh sample as strain $\mathrm{C}$, which did not contain any substitutions (45). Similarly, strains C9 and C11, each of which contained the same four substitutions near primer 473 in the $23 \mathrm{~S}$ rRNA, were isolated from the same site (but from different samples) as strain C12, which did not contain any substitutions. Strain A4, which contained the same substitutions as $\mathrm{C} 9$ and $\mathrm{C} 11$, was isolated several years earlier from a site that was $400 \mathrm{~km}$ distant. This type of variability did not correlate with other measures of diversity and, thus, contained little phylogenetic information. Instead, this distribution is consistent with allelic diversity within very large bacterial populations, where forward and back mutations are common.

Allelic diversity can obscure the evolutionary process in two ways. First, in highly related populations in which the number of inherited or phylogenetically significant substitutions is low, the apparent diversity depends on the individuals chosen to represent the population. This choice is largely random because allelic diversity is not correlated with phenetic and genetic measures of relatedness. And second, the presence of allelic diversity in modern populations implies that it also existed in ancestral populations. Because of the allelic diversity of the ancestor population, the sequence similarity of the founding individuals of modern populations is to some extent stochastic. If the founders happened to have the same allele, the observed substitutions in their descendents closely reflect the evolutionary process. If the founders happened to have different alleles, some of the observed substitutions are not due to inherited substitutions that occurred during the evolutionary process.

While these effects are likely, their importance in using rRNA sequencing to make taxonomic decisions has not been demonstrated. Because the number of substitutions in highly related taxa is small, it is difficult to distinguish clearly different sources of error, and more detailed studies will be necessary to determine the significance of allelic diversity in taxonomic analyses. Nevertheless, the presence of allelic diversity is important because it illustrates a potential weakness of many tree-building algorithms in common use, which are based on more simple models of evolution. In addition, it illustrates a potential pitfall in using oligonucleotide probes based on only a few sequences from a taxon, which may not be representative.

In an attempt to form taxa of uniform depth within the methanogens, Boone et al. (4) recommended 16S rRNA similarity values of less than $98 \%$ and 93 to $95 \%$ as evidence for separate species and separate genera, respectively. The average level of sequence similarity of $93.8 \%$ for the cluster containing $M$. voltaei, $M$. maripaludis, $M$. vannielii, and " $M$. aeolicus" is at the borderline for including organisms in the same genus. Similarly, the average values obtained in the reciprocal DNA hybridizations were low, (5 to $30 \%)$. However, given the absence of significant growth or biochemical differences, the separation of these species into more than one genus is not warranted. In contrast, the level of rRNA sequence similarity of $M$. thermolithotrophicus to this group is almost identical to the level of rRNA sequence similarity of " $M$. aeolicus," but in this case transfer to a new genus is supported by clear phenotypic differences (4).

At the species level, two groups of isolates exhibit sufficiently low levels of genetic relatedness to the type strains to warrant separate species descriptions. When they were compared with $M$. voltaei $\mathrm{PS}^{\mathrm{T}}$, heterotrophic isolates $\mathrm{A} 2$ and $\mathrm{A} 3$ exhibited about $37 \%$ DNA relatedness and $99.2 \% 16 \mathrm{~S}$ rRNA sequence similarity and had significant differences in their cellular protein patterns. The $\mathrm{G}+\mathrm{C}$ content of these organisms $(29.3$ $\mathrm{mol} \%$ ) is also slightly below the range of values found in typical $M$. voltaei strains (29.5 to $31.5 \mathrm{~mol} \%$ ). However, like $M$. voltaei, strains $\mathrm{A} 2$ and $\mathrm{A} 3$ require leucine, isoleucine, acetate, pantoyl lactone, and levels of $\mathrm{Mg}^{2+}, \mathrm{Ca}^{2+}$, and $\mathrm{Na}^{+}$typical of seawater for optimal growth $(45,46)$. Therefore, they are considered strains of $M$. voltaei. When they were compared with $M$. maripaludis $\mathrm{JJ}^{\mathbf{T}}$, autotrophic isolates $\mathrm{C} 5, \mathrm{C} 6, \mathrm{C} 7$, and $\mathrm{C} 8$ exhibited about $60 \%$ DNA relatedness, $99.2 \%$ 16S rRNA sequence similarity, and significant differences in their cellular protein patterns. However, the $\mathrm{G}+\mathrm{C}$ contents of these organisms and their growth responses to amino acids, acetate, and inorganic ions are within the ranges of typical $M$. maripaludis strains (45, 46). A possible difference is their slightly slower autotrophic growth rates. Therefore, strains $\mathrm{C} 5, \mathrm{C} 6, \mathrm{C} 7$, and $\mathrm{C} 8$ are considered $M$. maripaludis strains. This result illustrates the difficulties of using phenotypic differences to predict genetic differences in methanococci. Presumably, the lithotrophic niche of these bacteria is highly conserved and greatly restricts their growth properties. Thus, bacteria with very similar phenotypic properties may be very different at the genetic and molecular levels.

In contrast, $M$. deltae is genetically closely related to $M$. maripaludis $\mathrm{JJ}^{\mathrm{T}}$, which has priority, and should be considered a subjective synonym. Therefore, strain $\Delta \mathrm{RC}$ should be classified in the species $M$. maripaludis and referred to as $M$. maripaludis $\Delta$ RC. M. deltae was described largely on the basis of differences in growth responses to inorganic salts and an erroneous $\mathrm{G}+\mathrm{C}$ content determination $(9,45)$. In this case, reliance on the limited phenotypic characteristics that can be determined for these lithotrophs obscured the close genetic relationship between two bacteria.

The methanococcal phylogeny described above is notable because it suggests that the mesophilic methanococci are related to the exclusion of the hyperthermophiles $M$. igneus and $M$. jannaschii and the thermophile $M$. thermolithotrophicus. Moreover, thermophily is represented in both lineages formed by the deepest bifurcation of the Methanococcales. This pattern supports the hypothesis that the ancestor of this group was thermophilic and that mesophily is a modern adaptation. Even with the limited data available, this pattern is unusual outside the archaea. For instance, within the large and heterogeneous group previously assigned to the genus Clostridium, thermophilic subgroups appear to have arisen independently within mesophilic groups (7). In a similar vein, the deepest lineages within the methanococci are autotrophic, suggesting that autotrophy is an ancestral trait. Thus, the inability of $M$. voltaei to grow autotrophically may be a recently acquired characteristic. This hypothesis is consistent with the physiological evidence that $M$. voltaei contains the enzymes for autotrophic $\mathrm{CO}_{2}$ fixation even though most of its cellular carbon is obtained from acetate and amino acids (37). Thus, the ancestral methanococcus is likely to have been an autotrophic thermophile. 


\section{ACKNOWLEDGMENTS}

We thank Carl R. Woese, University of Illinois, in whose laboratory some of the rRNA sequences were determined, and J. L. Johnson, Virginia Polytechnical Institute and State University, for valuable advice.

This work was supported by National Science Foundation grants PCM-8351355 (to W.B.W) and DEB-9306171 (to C. R. Woese) and by Environmental Protection Agency contract AERL-9003 (to W.B.W).

\section{REFERENCES}

1. Amann, R. I., C. Lin, R. Key, L. Montgomery, and D. A. Stahl. 1992. Diversity among Fibrobacter isolates: towards a phylogenetic classification. Syst. Appl. Microbiol. 15:23-31.

2. Avise, J. C. 1994. Molecular markers, natural history, and evolution. Chapman \& Hall, New York.

3. Boone, D. R., and W. B. Whitman. 1988. Proposal of minimal standards for describing new taxa of methanogenic bacteria. Int. J. Syst. Bacteriol. 38:212 219.

4. Boone, D. R., W. B. Whitman, and P. Rouviere. 1993. Diversity and taxonomy of methanogens, p. 35-80. In J. G. Ferry (ed.), Methanogenesis. Chapman and Hall, Inc., New York.

5. Brosius, J., M. L. Palmer, P. J. Kennedy, and H. F. Noller. 1978. Complete nucleotide sequence of a 16 S ribosomal RNA gene from Escherichia coli. Proc. Natl. Acad. Sci. USA 75:4801-4805.

6. Burggraf, S., H. Fricke, A. Neuner, J. Kristjansson, P. Rouviere, L. Mandelco, C. R. Woese, and K. O. Stetter. 1990. Methanococcus igneus sp. nov., a novel hyperthermophilic methanogen from a shallow submarine hydrothermal system. Syst. Appl. Microbiol. 13:263-269.

7. Collins, M. D., P. A. Lawson, A. Willems, J. J. Cordoba, J. FernandezGarayzabal, P. Garcia, J. Cai, H. Hippe, and J. A. E. Farrow. 1994. The phylogeny of the genus Clostridium: proposal of five new genera and eleven new species combinations. Int. J. Syst. Bacteriol. 44:812-826.

8. Conway de Macario, E., M. J. Wolin, and A. J. L. Macario. 1981. Immunology of archaebacteria that produce methane gas. Science 214:74-75.

9. Corder, R. E., L. A. Hook, J. M. Larkin, and J. I. Frea. 1983. Isolation and characterization of two new methane-producing cocci: Methanogenium olentangyi, sp. nov., and Methanococcus deltae, sp. nov. Arch. Microbiol. 134:2832.

10. Devereux, J., P. Haeberli, and O. Smithies. 1984. A comprehensive set of sequence analysis programs for the VAX. Nucleic Acids Res. 12:387-395.

11. Devereux, R., S.-H. He, C. L. Doyle, S. Orkland, D. A. Stahl, J. LeGall, and W. B. Whitman. 1990. Diversity and origin of Desulfovibrio species: phylogenetic definition of a family. J. Bacteriol. 172:3609-3619.

12. Felsenstein, J. 1982. Numerical methods for inferring evolutionary trees. Q. Rev. Biol. 57:379-404.

13. Felsenstein, J. 1985. Confidence limits on phylogenies: an approach using the bootstrap. Evolution 39:783-791.

14. Felsenstein, J. 1991. PHYLIP-phylogeny inference package, version 3.4 . Department of Genetics, University of Washington, Seattle.

15. Fitch, W. M., and E. Margoliash. 1967. Construction of phylogenetic trees: a method based on mutation distances as estimated from cytochrome c sequences is of general applicability. Science 155:278-284.

16. Fox, G. E., J. D. Wisotzkey, and P. Jurtshuk. 1992. How close is close: 16S rRNA sequence identity may not be sufficient to guarantee species identity. Int. J. Syst. Bacteriol. 42:166-170.

17. Franklin, M. J., W. J. Wiebe, and W. B. Whitman. 1988. Populations of methanogenic bacteria in a Georgia salt marsh. Appl. Environ. Microbiol. 54:1151-1157.

18. Huber, H., M. Thomm, H. Konig, G. Thies, and K. O. Stetter. 1982. Methanococcus thermolithotrophicus, a novel thermophilic lithotrophic methanogen. Arch. Microbiol. 132:47-50.

19. Jackman, P. J. H. 1987. Microbial systematics based on electrophoretic whole-cell protein patterns. Methods Microbiol. 19:209-225.

20. Jarsch, M., and A. Bock. 1985. Sequence of the 16S ribosomal RNA gene from Methanococcus vannielii: evolutionary implications. Syst. Appl. Microbiol. 6:54-59.

21. Jarsch, M., and A. Bock. 1985. Sequence of the 23S rRNA gene from the archaebacterium Methanococcus vannielii: evolutionary and functional implications. Mol. Gen. Genet. 200:305-312.

22. Johnson, J. L. 1985. DNA reassociation and RNA hybridization of bacterial nucleic acids. Methods Microbiol. 18:33-74.
23. Jones, W. J., J. A. Leigh, F. Mayer, C. R. Woese, and R. S. Wolfe. 1983. Methanococcus jannaschii sp. nov., an extremely thermophilic methanogen from a submarine hydrothermal vent. Arch. Microbiol. 136:254-261.

24. Jones, W. J., M. J. B. Paynter, and R. Gupta. 1983. Characterization of Methanococcus maripaludis sp. nov., a new methanogen isolated from salt marsh sediment. Arch. Microbiol. 135:91-97.

25. Kersters, K. 1985. Numerical methods in the classification of bacteria by protein electrophoresis, p. 337-468. In J. A. P. Goodfellow (ed.), Computerassisted bacterial systematics, Academic Press, New York.

26. Kimura, M. 1983. The neutral theory of molecular evolution. Cambridge University Press, Cambridge.

27. Laemmli, U. K. 1970 . Cleavage of structural proteins during the assembly of the head of bacteriophage T4. Nature (London) 227:680-685.

28. Lane, D. J., B. Pace, G. J. Olsen, D. A. Stahl, M. L. Sogin, and N. R. Pace. 1985. Rapid determination of 16S ribosomal RNA sequences for phylogenetic analysis. Proc. Natl. Acad. Sci. USA 82:6955-6959.

29. Maniatis, T., E. F. Fritsch, and J. Sambrook. 1982. Molecular cloning: a laboratory manual. Cold Spring Harbor Laboratory, Cold Spring Harbor, N.Y.

30. Martinez-Murcia, A. J., S. Benlloch, and M. D. Collins. 1992. Phylogenetic interrelationships of members of the genera Aeromonas and Plesiomonas as determined by $16 \mathrm{~S}$ ribosomal DNA sequencing: lack of congruence with results of DNA-DNA hybridizations. Int. J. Syst. Bacteriol. 42:412-421.

31. Meakin, S. A., J. H. E. Nash, W. D. Murray, K. J. Kennedy, and G. D. Sprott. 1991. A generally applicable technique for the extraction of restrictable DNA from methanogenic bacteria. J. Microbiol. Methods 14:119-126.

32. Neumann, H., A. Gierl, J. Tu, J. Leibrock, D. Staiger, and W. Zillig. 1983. Organization of the genes for rRNA in archaebacteria. Mol. Gen. Genet. 192:66-72.

33. Olsen, G. J. 1987. The earliest phylogenetic branchings comparing rRNAbased evolutionary trees inferred with various techniques. Cold Spring Harbor Symp. Quant. Biol. L11:825-833.

34. Porter, D., and B. M. Sanborn. 1992. Analysis of heat-denatured DNA using native agarose gel electrophoresis. BioTechniques 13:406-410.

35. Rouviere, P., L. Mandelco, S. Winker, and C. R. Woese. 1992. A detailed phylogeny for the Methanomicrobiales. Syst. Appl. Microbiol. 15:363-371.

36. Schmidt, E. L., R. O. Bankole, and B. B. Bohlool. 1968. Fluorescent-antibody approach to study of rhizobia in soil. J. Bacteriol. 95:1987-1992.

37. Shieh, J., M. Mesbah, and W. B. Whitman. 1988. Pseudoauxotrophy of Methanococcus voltae for acetate, leucine, and isoleucine. J. Bacteriol. 170: 4091-4096.

38. Sneath, P. H. A. 1993. Evidence from Aeromonas for genetic cross-over in ribosomal sequences. Int. J. Syst. Bacteriol. 43:626-629.

39. Sneath, P. H. A., and R. R. Sokal. 1973. Numerical taxonomy. The principles and practice of numerical classification. W. H. Freeman, San Francisco.

40. Stackebrandt, E., and B. M. Goebel. 1994. Taxonomic note: a place for DNA-DNA reassociation and 16S rRNA sequence analysis in the present species definition in bacteriology. Int. J. Syst. Bacteriol. 44:846-849.

41. Stein, A., N. A. Saunders, A. G. Taylor, and D. Raoult. 1993. Phylogenetic homogeneity of Coxiella burnettii strains as determined by $16 \mathrm{~S}$ ribosomal RNA sequencing. FEMS Microbiol. Lett. 113:339-344.

42. Tonjum, T., G. Bukhoim, and K. Bovre. 1989. Differentiation of some species of Neisseriaceae and other bacterial groups by DNA-DNA hybridization. APMIS 97:395-405.

43. Wayne, L. G., D. J. Brenner, R. R. Colwell, P. A. D. Grimont, O. Kandler, M. I. Krichevsky, L. H. Moore, W. E. C. Moore, R. G. E. Murray, E. Stackebrandt, M. P. Starr, and H. G. Trüper. 1987. Report of the Ad Hoc Committee on Reconciliation of Approaches to Bacterial Systematics. Int. J. Syst. Bacteriol. 37:463-464.

44. Whitman, W. B. 1989. Methanococcales, p. 2185-2190. In J. T. Staley, M. P. Bryant, N. Pfennig, and J. G. Holt (ed.), Bergey's manual of systematic bacteriology, vol. 3. The Williams \& Wilkins Co., Baltimore.

45. Whitman, W. B., J. Shieh, S. Sohn, D. S. Caras, and U. Premachandran. 1986. Isolation and characterization of 22 mesophilic methanococci. Syst. Appl. Microbiol. 7:235-240.

46. Whitman, W. B., S. Sohn, S. Kuk, and R. Y. Xing. 1987. Role of amino acids and vitamins in nutrition of mesophilic Methanococcus spp. Appl. Environ. Microbiol. 53:2373-2378.

47. Woese, C. R., L. Achenbach, P. Rouviere, and L. Mandelco. 1991. Archaeal phylogeny: reexamination of the phylogenetic position of Archaeoglobus fulgidus in light of certain composition-induced artifacts. Syst. Appl. Microbiol. 14:364-371. 